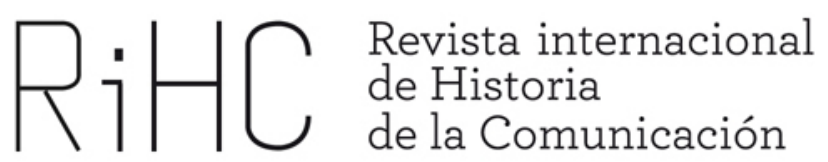

\title{
A HISTORY OF JOURNALISM ON THE INTERNET: A state of the art and some methodological trends
}

DOI: http://dx.doi.org/10.12795/RiHC.2013.i01.12

\author{
Javier Díaz Noci \\ Universitat Pompeu Fabra \\ javier.diaz@upf.edu
}

Resumen: La historiografía de los nuevos medios ha ido adquiriendo, sobre todo en la última década, una considerable importancia, especialmente aquella dedicada a la investigación histórica sobre la World Wide Web (vide Brügger, 2010). Peviamente, la hisotria de los medios de comunicación se había beneficiado de la perspectiva de la historia social y cultural, representada, entre otros, por Burke o Briggs. Desde esos puntos de vista, intentamos en este artículo explicar la historia de las primeras décadas de periodismo en internet, y poner de manifiesto algunos retos metodológicos relacionados con la investigación histórica sobre el tema.

Palabras clave: Historiografía; Internet; World Wide Web; Historia; Periodismo.

\begin{abstract}
Historiography of new media has gained a remarkable importance in the last decade, especially that devoted to the historical research about the World Wide Web (i.e., Brügger, 2010). Previously, the history of the media was enforced by the perspective of the social and cultural history currents (Burke; Briggs). From these points of views, we attempt in this paper to trace the history of the first decades of online journalism, and to highlight some methodological challenges related to historical research applied to it.
\end{abstract}


Javier Díaz Noci

Keywords: Key words. Historiography. Internet. World Wide Web. Online Journalism. History. 


\section{Introduction}

\subsection{Is historiography suitable to study the Internet and online journalism?}

A first focus when we do research on new media is history. The relationship between journalism and historiography has been highlighted by the History of the Present by Timothy Garton Ash. There were already histories of journalism prior to the implantation of journalism studies in our universities, of course, with their different approaches and very different contributions depending on the object of study or the ideology of the person making them. They have been continued to be produced until the present, with a marked national focus, equally reproduced to history of journalism on the Web (Brügger, 2010: 350) of which a good example is a, on the other side, excellent book on online Portuguese journalism (Bastos, 2010). It would seem logical, thus, to think that the same historiographical currents and methodologies could be applied to the study of the new media.

There is, however, an initial problem: can one try to make a history of such a recent phenomenon? Many historians are reticent to make a history of periods they consider to be unfinished, others prefer to start to make a history from the very moment that this is merited by the object of study, from the moment that it shows its social transcendence. One example of this is the volume entitled Web History, dating from 2010 (Brügger, 2010). And work has yet to be done exploring all of the other earlier manifestations, if only because they prepared the path towards what would later be online journalism. If we had to cite two fundamental books that were visionary - but not divinatory, which is why they continue to be relevant - and that were capable of seeing the importance of the approaching phenomenon, these would without any doubt be the Nora-Minc report, on the one hand, and the seminal book by Anthony Smith Goodbye Gutenberg, on the other.

Prestigious historians have concerned themselves with the Internet. Robert Darnton, for example, who in 1999 wrote a very interesting text in the New York Review of Books about the possibilities of digital publishing, and made proposals that are equally applicable in the field of journalism (see Díaz Noci, 2001: 145-150). Robert Darnton's proposal inquires into the possibilities of digital publishing, both in its temporal dimension and with respect to the reader's memory or participation (Darnton, 1999). He himself applied his proposals in a famous article that was published in the American Historical Review in 2000.

We have an advantage in facing older media like the printing press: while historiography took five centuries to inquire into the immense transformation and 
social transcendence of the printing press (the work of Elisabeth Eisenstein, besides establishing a model, is already a classic; Eisenstein, 1979), in the case of Internet such academic concern is almost contemporary with the phenomenon it studies. Other well-known historians, like Roger Chartier, Peter Burke or Asa Briggs, have already offered interesting reflections on the electronic document and on changes in cultural production and reading.

\subsection{The Object of Study}

Some time ago the historiography of communication attempted to supersede a merely positivist and heuristic phase - without, on the other hand, there being anything bad or reductionist in that approach, especially if it is employed in the first phase of the study concerned. Newspaper catalogue studies would correspond to this first phase.

It would be useful if we were to apply the interpretation of the text made by sociocultural history to these results, and also to the new discourse based on the hypertext (Burke, 1992: 98 ff.; Hunt, 1989; Cavallo and Chartier, 1998: 43). It is not always appropriate to share that "culturalist determinism that time and again revolves around 'texts' and that concentrates exclusively on discourses and representations alone" (Gracia, 2005: 41). It would thus be a case of combining content analysis, even the pragmatics of the text (the work of Teun A. van Dijk provides a model both with respect to the determination of the typical structures of the news story and with respect to the transmission of certain ideologies through types of concrete texts), with a vision that places the human being, understood as a social subject, at the center of historical interpretation.

\subsection{The Digital Document: Problems}

In a society like ours, where millions of web pages are read each day, and where there are in addition millions of commercial and banking transactions, airline ticket sales, and exchanges of commercial and professional correspondence in electronic form, the proposal to conserve and classify that enormous mass of volatile information is one of the great questions facing historiography today. This was highlighted years ago by R. J. Morris (in Higgs, 1998: 31-48): the obsolescence of the formats that contain digital information, the obsolescence of programs, browsers and operating systems that make it possible to read that information, and the problems of cataloguing documents in a continuous state of mutation, so different from printed books or journals.

In Digitising History, Townsend, Chappel and Strujvé insist on those questions from a more pragmatic point of view. It is not only a question of digitizing documents, but also 
of making them accessible to the scientific community in the form of databases, and that is where their structure and architecture becomes crucial. In any case, the concept of library (and press archive) is clearly moving from a physical state to a virtual one, with all the changes that this implies. Not only a saving in terms of physical trips that the researcher was forced to make, which at times followed a route that was no doubt instructive in touristic terms but economically expensive, but also a saving in the time spent in pursuing the material sought.

For any kind of historical research, archives are important. Digital documents, as mentioned before, pose some problems, so digital preservation is the solution (Cohen \& Rosenzweig, 2005, especially the chapter about 'Preserving digital history: The future of our digital past'; for audiovisual digital archives, see Hiroux, 2009). Online newspapers' archives -we are talking about the archives of the online newspapers, not about the digitized archives of the printed ones, which is also an important, but different question- pose particular problems (Guallar \& Abadal, 2010). Despite the few years of existence, compared with all the other media, until recently there have been no clear strategy on digital preservations (Keefer \& Gallart, 2007). Public institutions and libraries are not able to preserve all which is produced by digital companies, and it seems necessary to give them some clear and univocal guidelines so that the major ones could proceed to preserve -and place them to the disposal of the scholarly community- their patrimony (Deegan \& Tanner, 2006). Some efforts are being doing in national libraries, mainly, which in 2003 created the International Internet Preservation Consortium) ${ }^{1}$. In 2008, the Virtual Knowledge Studio of the Amsterdam and Maastricht University started a project called The In-Between Machine ${ }^{2}$, which tried to fin "new ways for preserving web archives together with their contexts of creation and use" (Van den Heuvel, 2010: 281).

Nonetheless, some tendencies can be discerned in this period of the implantation and early development of online journalism. One is a periodization that is linked to entrepreneurial aspects and business models ("Show me the money" is the title of an article on this question by John Pavlik, published in September 1997 in the Colombia Journalism Review). John Pavlik introduced a debate that has often been in the foreground: whether "this" (the digital edition) will kill off "that" (the printed edition), which is a deceptive debate that at the time of the invention of the printing press had already been raised with respect to the manuscript. One only has to read Eisenstein to realize to what extent some debates from that time are now being reproduced as well. This is a point that does seem to me interesting when it comes to writing a history of online journalism, and not only, nor principally, from a merely technical point of view.

$1 \mathrm{http} / / /$ netpreserve.org/about/index.php

2 http://www.edata.nl/0303_011208/pdf/The_In-Between_Machine.pdf 


\section{History of online journalism and online news: an essay}

\subsection{Precursors}

In the 1980s, the BBS, which were offered through the personal computer not the television, were a cheaper alternative to videotext. This was the time of CompuServe, Prodigy and America OnLine (AOL). One of the first newspapers offering its services on CompuServe was The Wall Street Journal, and the financial information was the one to prove that there was some room for payment news on the Internet. In the 1990s, some important North American newspapers took up this system, which was clearly a prelude to what was shortly to be the journalism of the World Wide Web, then in a phase of gestation. Some (not mainstream) media, but during the first years of the decade, some printed media (Nando in the United States, for instance) began to publish a Bulletin Board System (BBS) edition.

In 1994 the first newspapers were published on the WWW: the Palo Alto Weekly dates from January that year. Some months before, at the end of 1993, the University of Florida launched the first website on journalism. 1995 is a key year, as there were already 150 newspapers on the WWW, and the magazine Editor \& Publisher dedicated a monographic issue to the new phenomenon. Time magazine dedicated another special issue to cyberspace on March that year. The opening text by Philip ElmerDewitt traced some of the prejudices against cyberspace and online news installed amongst us from then onwards:

The rush to get online, to avoid being 'left behind' in the information revolution, is intense. Those who find fulfillment in cyberspace often have the religious fervor of the recently converted [...]. Largely unedited, its content is often tasteless, foolish, uninteresting or just plain wrong (Elmer-Dewitt, 1995.)

But, at the time and in the same magazine issue, the managing editor James R. Gaines recognized that "the decision to go online has meant that our editors, writers and correspondents have been familiarizing themselves with yet another new journalistic venue: the ongoing exchange of real-time computer messages with our readers." Time magazine, like some other media, had started in 1995 "an electronic dialogue between journalists and their audiences" (Allan, 2006: 15). 


\subsection{Media Take a Position on the Web}

When the World Wide Web was launched, rapidly it became very popular, and then, in 1994-1995, some media companies all over the world began considering going through that service, and began to abandon Servicom or CompuServe. Some newspapers are considered to be the pioneers of Web journalism: in the United States, Chicago Tribune was distributed by America OnLine (AOL) since May 1992, and then, in 1993, San José Mercury Center, Nando.net (an online version of the community local daily newspaper Nando Times) decided to go online, The Boston Globe decided some time later to create a community board and in Europe, one of the first was The Electronic Telegraph, an online version of The Telegraph.

Also some experiments on tablets were done at the moment. Roger Fidler, from Knight-Ridder, proposed the flat panel in 1994, but the research project was cancelled by the group by $1996^{3}$. The British Evening Standard also proposed a similar concept, the Newsbox, but it was never launched. Between 1994 and 1996, a group headed by Mario Santinoli, then working for El Periódico de Catalunya, developed a prototype called NewsPad, which really worked, but was never commercialized.

Alliances began. The then dominant browser company, Netscape Communicator, made a joint venture with Reuter, $\mathrm{ABC}$ Television, The New York Times, The Boston Globe, Times Mirror and Los Angeles Times in 1996. That year, Microsoft and NBC created a cable and Internet television, MSNBC.

The online audience was also taking shape. William Casey, the director of computerassisted reporting at The Washington Post, saw two group, the first consisting "of newspaper readers with a need to see publications to which they normally don't have access", and the second one consisting of "those with a specific interest in particular subjects or policy areas" (mentioned in Driscoll et al., 2005: 15).

The mainstream major media decided to take some time before placing a website. Le Monde Interactif (today LeMonde.fr) was placed in December 1995. The New York Times On The Web (now just The New York Times) debuted in January 1996. El País Digital (now El País.com) appeared for the first time on the Web in May 1996, when most of their competitors were already online. One of the most important online media all over the world, and a model in many ways, $B B C$ News, went online only in November 1997 (Thorsen, Allan \& Carter, 2010), since the Web audience was growing $10 \%$ every month, "an initiative within the Corporation's strategy to reaffirm its publics service ethos in a multi-channel universe, and thereby be better placed to challenge

3 See Williams, J. (2011) 'The tablets' long story'. Wired, <http://www.wired.com/geekdad/2011/10/the-tablets-long-history/\#more-91099>. Accessed: November 25, 2011; Aumente, J. (1994). Panel Vision. American Journalism Review <http://www.ajr.org/Article.asp?id=1257> 
rivals such as CNN [its website CNN Interactive was successful at the time], MSNBC, Euronews, and News Corp." (Allen, 2006: 35) ${ }^{4}$. In fact, there were conversations with Microsoft, which had led BBC News to be 'MSBBC' (Smartt, 2007). They began with just 40 journalists working for the $\mathrm{Web}^{5}$, but multi-skilled from the very beginning. In just one year, by $1998, B B C$ News, which was described by M. Smartt as a hybrid of formats or a dynamic newspaper, and also a third broadcast medium (Smartt, 2007) was considered the leading British Internet site.

\subsection{Consolidation Period: First Steps towards an Original Model}

Anyway, by 1996 there were some professional models, not merely exploratory, but conscious of doing some steps towards a proper journalistic and business model. There was an emerging market, and an attempt to differentiate online versions from the print ones. San José Mercury Center, online version of San José Mercury News from California, published a report series on the sale of cocaine in Southern California, which created much controversy, and they gave birth to an interactive strategy with readers which is now a common practice in the online world. It was followed by Dallas Morning News, the first one in deciding to give a scoop online, "because they feared CNN would scoop" (Salwen, Garrison \& Driscoll, 2005: 3-4). From 1996-1997 media companies confessed that they were seeking for a business model, so they needed to launch an attractive offer to consumers. Online editions were not merely shovelware, and newsrooms tried to develop some specificity as well. A new question arose: convergence. Around those years, at least in the United States, online media were not sure about where they were going to.

Matt Drudge's Drudge Report was created, primarily as a collection of links to other sites, but with occasional breaking news, a model which, with some modernized characteristics, has inspired much more online media, and even Huffington Post. When in 1998 Kenneth Starr presented their report on US president Bill Clinton's sexual affair with Monica Lewinsky, Drudge Report posted for the first time a mention to it, and immediately, many media of the world reproduced, link or translated the many pages

\footnotetext{
${ }^{4}$ The Corporation of the BBC had launched previously, in 1994 and 1995, some special sites: The BBC Networking Club was launched in June 1994, and Budget '95 was prepared in 1995 in collaboration with the Press Association, another one in November 1996. The last test, so to be said, was the site Election 97, when prime minister John Major announce the next elections' date (Thorse, 2010: 216)

5 "Or rather, there weren't. A few bright, prescient individuals came from other BBC departments to work on the web, but most people in the organisation viewed the new setup as a bunch of anti-social nerds, doomed to failure. So text journalists - text and a few still pictures being the early staple of all Internet news sites - were recruited from outside." (Smartt, 2007). On the history of BBC News online, see also Butterworth, 1999 and 2007.
} 
of the Starr report through Matt Drudge's site. "Newspaper readers will have to rely on summaries," said in 2000 Hans-Jürgen Diller, because "the most obvious difference between the Internet and a printed newspaper is that no paper can afford to publish a document the size of the Starr Report (445 pages!)" (Diller, 2000: 208). The credibility of online media was failing, to some extent, but such documentary resource helped recover it.

Another characteristic, alongside with hypertext, multimedia or interactivity, became extremely important for online media: real time or immediacy. The great debate of the times was if this was to kill that, if Internet would substitute the printed page. The report The Future of the Printed Press Challenges in a Digital World, whose title is meaningful, of the European Journalism Centre, pretended that the transmission of information was changing and focused on economics and the role of journalists in the new digital environment, nevertheless it was about giving some advices to newspaper industry to save its business. The number of newspapers on the Internet was increasingly growing. A report by Bernardo Díaz Nosty, commissioned by the European Journalists Association, was presented in September 1998 in Porto (Portugal) during the 4th Forum Euro-Latin-American of Communications. The report said that all over the world there were more than 10,000 media with some presence on the Internet. 2,284 were daily newspapers. English was the main language (1,236 titles), more than $54 \%$ of them all. The second language, quite far from English, was Spanish, 325 dailies from 22 Spanish-speaking countries, $14,2 \%$ of all ${ }^{6}$.

As Pablo Boczkowski demonstrated in his PhD thesis, the culture of innovation of the media was based in a combination of reactive, defensive and pragmatic characteristics, far from the technological determinism, which came from Marshall MacLuhan and which was claim to be surpassed by, amongst other scholars, Neil Postman as well. At least, some other scholars prefer to substitute it for "a pluri-determinism", because there are several driving forces leading all the process (Brügger, 2010: 31). At the moment, according to a report of 1998 by The Pew Research Centre, 20 per cent of the Americans connected at least once a week to the Internet to get some news, 36 million people. That still seem not to have any incidence in the press business, whose readers and buyers were exactly the same that before, more or less.

Online infographics were also common at that time. Online staffs grew up as well, and media webs were converted into portal, following a model began by Yahoo!, Netscape, America On Line (AOL) and Lycos. This was especially clear in Brazil, where Globo Group, one of the largest media-companies in Latin America (and all over the world) controls a majority of media in this huge country and determines the shape of many media-based websites (Herscovitz, 2009). In Europe, such model was not totally successful. One example is Le Monde which, through its trademark Le Monde

${ }^{6}$ El País, October 15, 1998. 
Interactif, decided to launch a portal called tout.lemonde.fr in the Spring of 2000, and abandoned it in June of the same year.

A model for online media was $B B C$ News, which by March 1998 had 8,17 millions page impressions and was offering 61,000 news items (Thorsen, Allan and Carter, 2010: 119), and in 1999 resisted the pressure to become a commercial operation. They did a bet on interactivity, and they won.

The attacks against the World Trade Center in New York during September 11, 2001, were a milestone for journalism, and online journalism had to suffer an 'acid test" Most of the online news almost collapsed, CNN.com and ABCNews.com find themselves unable to display videos, WSJ.com became free of charge that day, but at the same time the millions of visits online media received $(10,6$ milions The New York Times, 17,2 million people CNN.com, for instance) proved the existence of a real demand of this kind of immediate and at the same accurate information (Allen, 2006: 53-71).

\subsection{The First Crisis: The Challenges of the Multimedia and Interactive Model}

Around 2002 began another period for online media, since some of them decided to explore payment models, seeking not for readers, but for economic profits; "news organizations have no incentives to produce original online news" (Driscoll et al., 2005: 47), and they needed investments. Design was also renewed, and some moves in manager staff occurred in many media. The number of online newspaper reached in 2002 the number of 2,959 all over the world, as estimated by the World Association of Newspapers. At the same time, online media were "responding to the increased sophistication of online readers, providing more multimedia features, deeper content and frequent updates" (Greer and Mensing, 2003).

The attacks against of Madrid, in March 2004, and London, in July 2005, marked another milestone in online journalism's development. Online newspapers were prepared for covering such an event, and, for instance, Guardian.co.uk obtained 1.3 million unique visitors and served 7.8 million pages. Online media were able to react and satisfy the expectative created. First of all, as Fogel and Patiño remembered, the frontier between journalists and audience disappeared; just some minutes after the explosion in England, the BBC newsroom received the first images sent by the citizens. That day, Internet became the primus inter pares in media system (Fogel \& Patiño, 2005).

\footnotetext{
${ }^{7}$ Most of the websites dealing with September 11 can be consulted at the September 11 Web Archive (http://september11.archive.org), collected by the US Library of the Congress.
} 


\subsection{A Proper Model}

Around 2006-2007, the use of Really Simple Syndication systems (RSS), reporter blogs ${ }^{8}$, video, comments and podcasts was a common practice, although the first documented use of blog -an edition platform appeared as we know it in 1994, but popularized in 1999 with the creation of the free Pitas platform- to cover a breaking news story was in 1998 in the Charlotte Observer, in occasion of Hurricane Bonnie (Tunney \& Monaghan, 2010: 31) ${ }^{9}$, and was the prelude for further witnessing journalism, of which an example is the coverage of Hurricane Katrina in 2005. But it was in two moments, during the Iraq War in 2003, when CNN.com correspondent Kevin Sites published his own blog giving his personal comments on situation, MSNBC used three blogs ('Weblogs are journalism', said Joan Connell, executive producer -see Allen, 200: 108), and freelancer Christopher Allbitton announced that he would covered the war using his blog, Back to Iraq 2.0 $0^{10}$ (http://www.back-to-iraq.com/), a model that was followed by some other journalists in the world, i.e., David Beriain, then working for the Spanish newspaper La Voz de Galicia and 2004, during the US presidential campaign, that the use of this publishing platform became extensive amongst journalists. Blogs were used as a source as well, and were at the origin of witness journalism. Probably the most famous one was Where is Raed. Later on, social networks have been extremely useful to cover foreign affair in countries where censure already exists, but this has not avoided unethical practices on the Web and outside it.

Participatory journalism, a term which in 1970-1980 meant "journalists participating in the events" became a common expression now to refer to users taking part in the news process: media needed to offer, in spite of their initial reluctance, their readers blogs, comments on stories, message boards, polls, Q\&A, etc. (Thurman \& Hermida, 2010: 48). Approximately $97 \%$ of the American online media were using RSS in 2007, 95\% had reporter blogs, $92 \%$ of them used video, and $49 \%$ of them offered podcasts (the figures were of $76 \%, 80 \% 61 \%$ and $31 \%$ the year before, according to the World Association of Newspapers and the Bivings Group). Probably the most outstanding characteristic incorporated by online media, especially by newspapers' websites, was video, influenced by the emergence of YouTube in $2004^{11}$. Some properly participatory or citizen-journalism devoted media (also called open source reporting media) appeared in the first years of the new millennium, like IndyMedia, OhmyNews

\footnotetext{
${ }^{8}$ For example, “In October 2004, Le Monde.fr opened a blog platform for subscribers, as well as their own paper columnists. One of Le Monde's political news correspondents based in New York and Washington, Corine Lesnes, was one of the first to blog on Le Monde.fr."

${ }^{9}$ ttp://web.archive.org/web/20010417195542/www.charlotte.com/special/bonnie/0820dispatches.htm

${ }^{10} \mathrm{http}: / /$ www.wired.com/politics/law/news/2003/03/58043?currentPage=all

${ }^{11}$ YouTube was acquired by Google in October 2006.
} 
and Wikinews. Financial problems have reduced the importance of at least the two last ones in the recent years.

By 2008, the WWW was the second information source for the American audience, according to State of the News Media (Nieman Foundation, 2009) and a report by the World Association of Newspapers and IFRA, and adoption of the social web was world widespread by this year as well; almost every online media in the world had its Facebook and Twitter facilities. An increasing percentage of the audience of online media comes from search engines, especially Google (Andrews, 2007). On the other hand, an also increasing percentage of the visit to online newspapers comes from social networks; e.g., $8 \%$ of the visits to the Telegraph.co.uk came from Twitter in 2009 (Coles, 2009).

The content offered by the online media is tending to be more and more properly created for the Web, instead of being a mere adaptation of the printed (or even audiovisual, in the case of radio and television-based websites) material. Somewhere during the first decade of the 21st century, the division was not between digital natives, "native speakers of the digital language of computers, video games and the Internet", and digital immigrants, "those of us who were not born into the digital world but have, at some later point of our lives, become fascinated by and adopted many or most aspects of the new technology" (Prensky, 2001), but between visitors, those who "see the Web as primarily a set of tools which deliver or manipulate content", and residents, those who "see the Web as a place [...] a proportion of their lives is actually lived out online where the distinction between online and off-line is increasingly blurred" (White and Le Cornu, 2011).

If we translate this metaphor to media, this should be near to the attitude and strategy adopted by, for instance, The Guardian, which in 2011 decided to offer all its content "Web first"12. The decision was conditioned by the fact that only $4 \%$ of their readers confessed that they knew news for the first time reading the printed newspaper so, they concluded, they read the paper in a more calmed way, preferentially on the evening, as explained by Andrew Miller. The Guardian's editor-in-chief, Alan Rusbridger, explains that "if I want to be conservative in order to protect The Guardian, my instinct says that I have to be more conservative for the online ${ }^{13}$. In any case, the timing of news production has changed over the years: in 2009, as published

\footnotetext{
12 Web First: Guardian and Observer to adopt 'digital-first' strategy | Media | guardian.co.uk: http://www.guardian.co.uk/media/2011/jun/16/guardian-observer-digital-first-strategy. See also http://www.guardian.co.uk/gnm-press-office/guardian-news-media-digital-first-organisation

${ }^{13}$ Both Miller's and Rusbridger's words appeared in Echevarría, Borja (2011). "La prensa hace catarsis rumbo al futuro". El País.com <http://www.elpais.com/especial/35-aniversario/el_pais_delfuturo/la_prensa_hace_catarsis>. Access: October 20, 2011. This article's author believes in a hybrid model for the next future.
} 
by the Newspaper Association of America, $62 \%$ of the newspapers in the United States were published to be sold around 6 am.

Even the most reputed (online) newspapers of the world did not refuse to publish more than 250,000 diplomatic cables discovered by Wikileaks in November 2010. The selection and publication of those documents an old debate emerged, amplified by the immediacy and power of the Internet, which put on the hands of the world thousands of sensitive information with little mediation. In a first moment, Wikileaks creator Julian Assange advanced in June 2010 the next publication of those US ambassadors' cables, since Assange thought (which is a good indicator that newspaper industry is in good health condition "that this story would have a greater impact if he was willing to work together with newspapers" (Carvajal, García Avilés \& González Esteban, 2011: 84). The Guardian, The New York Times and Der Spiegel accepted to publish the material, and some time later El País and Le Monde joined them. A huge amount of text needed to be revised, and then the media launched some special sections of their websites. At least two of the, Guardian.co.uk and EIPaís.com, created a database interface to facilitate users the search for information and display the documents. Even if the cables were considered "to be embarrassing, more than damaging," as Alan Rusbridger, editor of The Guardian said, the affair stirred considerably the Net and the public opinion, posed some ethic and professional problems, produced a debate on censure, freedom of speech and state secrets, even on the nature of journalism, what was considered to be news, the opportunity of publishing such data, and finally the pressure led to the economic strangling of Wikileaks in November 2011, just one year after the so-called Cablegate exploded.

\section{Discussion and further research}

The already short history of online journalism shows a tension between which can be technically done and which is finally offered by the companies. Asynchronicity and synchronicity are no longer the privileges of no media, so newspaper newsrooms are learning how to accurately publish live coverage of news, and how to integrate video, sound or infographics with text, and, to the other hand, audiovisual media are learning how to plan coverage of news incorporating text, and how to conceive them as a not necessarily perishing and evanescent product. All of them are developing new strategies, which include a conception of their media as a database, and of news as modular pieces susceptible of being linked to any other news item, so information is networked and not composed of efforts destined to a rapid obsolescence. 
But curiously, at the same time, historians are facing problems to recover digital information, since no clear strategy was implemented in the first years of the presence of media on the World Wide Web to preserve their digital products. For further research, we propose to ask the online companies included in our research universe which have been and are the measures to preserve their digital inheritance, which are the strategies and guidelines given by libraries and public record institutions to preserve that, and be able to trace a state of the art and give some recommendations as well.

Regarding to history, we propose to use interviews to carry on a prosopographical study. Prosopography is the collective biography of a human group, e. g. a profession, based on comparing similar records (education, professional trajectory, intellectual production, responsibility charges and jobs, etc.) for all their individuals. In our humble opinion, it is possible to do a dictionary of online journalists in spite of the youth of the research object and, because of it, to develop this part of future projects more as a continuously completed online dictionary than as a closed book. The experience of the members of the group in interviewing makes recommendable to use this methodological tool (in this case, more the type of the interviews used in oral history, narrative interviews, than semi-structured ones, more extensively used in ethnographical studies) to ask the editors-in-chief of the media we study for the moments of change and evolution of online media, so episodic interviews would be of some help as well.

Those new technologies and advances do not have to lead us to determinism of any kind. In spite of the clear advantages and challenges of the online world, let us remind that abundance of information does not necessarily mean not better information, neither more news items. Ownership concentration, in spite of all legal measures, is a reality all over the world. So probably we would do our best if we could merge on some investigation on media property, and it has come the time to do some research about to which extent online media ownership is a different landscape. In other words: to which extent news items are more and more plural, and in which hands they are.

The research we have been able to carry on until now reveals some interesting trends of an already immature medium. An enormous gap appears between quality media and amongst them as well, since journalistic traditions are, in this respect, equally important- and other media. In those media that have made a commitment towards quality, and have renounced to visibility given by a great amount of comments, show the path towards two models: communities of debate and homogeneous communities. Our humble studies point out the route towards any of each, and it means intervention and, moreover, investment in collaborative intelligence. Media organizations control the flux of information -the great amount of news agencies demonstrate this, and not only in online media-, so information is already centralized; we would do well to not 
confound production and re-production, even though if both of them are important. Reproductions leads people to variation and interpretation, which is excellent, but the origin of the news is already in the hands of relatively few people -another field of study, certainly. If newspapers as we knew so far are the result of the technical possibilities of printing and distribution of the industrial revolution, the slow rise to power of the working class and of representative democracy, the picture in the last fifteen years we have drawn begins to be something else. In fact, scholars such as Anthony Smith believe that "a golden age of newspapers began in 1960 and ended in 2005" (Smith, 2010: 8). Speaking to Esquire in May 2009, the CEO of the powerful, though financially strapped, and only saved by the injection of U.S. capital in 2010 Spanish group Prisa, Juan Luis Cebrián, said that "mediation, which is what characterizes representative democracy is disappearing." In fact, all this have more to do with economy, formerly of the economy of the offer and now the economy of demand and attention, and with profit margins. Today, digital media are far away, as a rule with few exceptions, some of which have been mentioned in the paragraph above, to achieve margins as those of $20-30 \%$ of the newspapers. This is why, supposedly, an online medium, or a medium in crisis ${ }^{14}$ cannot afford good correspondents or war journalists. At this time, and against what can be said selfishly from media companies, we are not talking about alternative or substitution technologies. We are talking, as we have repeatedly said in this text, about a long transition, such as that occurred between the manuscript and the printed book, which Elizabeth Eisenstein so well described in her books.

Making a long story short, we could say that we find ourselves confronting a "crisis of a form of production which has been made obsolete and anachronistic by new technical discoveries [...]", since "we stand in the midst of a powerful process of the transformation of forms, a process of transformation in which many of the oppositions with which we used to work could lose their power", a dialectical moment in which "the realm of literature gains in width what it loses in depth", when "the difference between author and public, maintained artificially by the press, is beginning to disappear", a time in which the newspaper is in a "showplace of confusion", in which, for better or worse, consumers and readers show signs of "the impatience of whoever feels himself excluded, whoever thinks he has a right to express his own interests himself". A scenery in which "the indiscriminate assimilation of facts goes hand in hand with the similar indiscriminate assimilation of readers, who see themselves instantly raised to the level of co-workers", in which we might ask whether we are dealing with a revolution or simply feeding "an apparatus of production without transforming it", if the challenge is to lead "consumers to production, [...] making co-workers out of

\footnotetext{
${ }^{14}$ Both Miller's and Rusbridger's words appeared in Echevarría, Borja (2011). "La prensa hace catarsis rumbo al futuro". El País.com <http://www.elpais.com/especial/35-aniversario/el_pais_delfuturo/la_prensa_hace_catarsis>. Access: October 20, 2011. This article's author believes in a hybrid model for the next future.
} 
readers or spectators." In short, "the best opinions won't help, if they don't make something useful out of the person who holds them."

These words were written by Walter Benjamin in a book entitled Der Author als Produzent in 1934, and more than 75 years later they have not lost -I believe- their validity.

\section{References}

ALTERMAN, ERIC (2008). Out of Print. The Death and Life of the American Newspaper. The New Yorker, March 31. <http://www.newyorker.comreporting/2008/03/31/080331fa-fact_alterman>. Accessed: October 20, 2011.

ANDREWS, R. (2007). Search engines drive more readers to news sites.

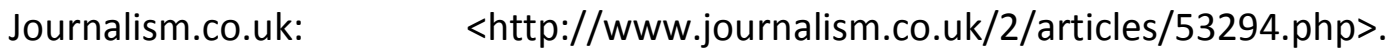
Accessed: December 1st, 2009

BARBOSA, SUZANA; MEIRELES, SUZANA (2009). Microjornalismo como modalidade emergente da Web 2.0. In: I Congreso Internacional de Ciberperiodismo y Web 2.0. Bilbao, November 11th, 12th and 13th. Bilbao: University of the Basque Country.

BASTOS, HELDER (2010). Origens e evoluçao do ciberjornalismo em Portugal. Os primeiros quinze anos (1995-2010). Porto: Afrontamento.

BOCZKOWSKI P.J.; DE SANTOS, M. (2007). When more media equals less news: Patterns of content homogenization in Argentina's leading print and Online newspapers. Political Communication, 24(2): 167-180.

BOCZKOWSKI, P. J.; FERRIS, J.A. (2005). Multiple Media, Convergent Processes, and Divergent Products: Organizational Innovation in Digital Media Production at a European Firm, The Annals of the American Academy of Political and Social Science, 597: 32-47.

BOCZKOWSKI, PABLO (2004a) The processes of adopting multimedia and interactivity in three online newsrooms, Journal of Communication, 54: 197-213.

- (2004b) Digitizing the News: Innovation in Online Newspapers (Inside Technology). Cambridge: The MIT Press. 
- (2004c). The development and use of online newspapers. What research tells us and what we might want to know. Lievrouw, L.; S. Livingstone (eds.). Handbook of new media. London: Sage, 2004: 270-286.

- (2009). Materiality and Mimicry in Journalism Field. In B. Zelizer (ed.): The Changing Faces of Journalism: Tabloidization, Technology, and Truthiness. London; New York: Routledge: 56-67.

BRIGGS, ASA; BURKE, PETER (2002). A Social History of the Media. Cambridge: Polity.

BRÜGGER, N. (ed.) (2010). Web History. New York, etc.: Peter Lang: 213-232.

BURKE, PETER (1992). History and social theory. Cambridge: Polity Press.

CARVAJAL, M.; GARCíA AVILÉS, J. A.; GONZÁlEZ ESTEBAN, J. L. (2011). The News Production Process about the U.S. Embassy Cables: How The Guardian, The New York Times and El País Covered and Released the Documents Provided by Wikileaks. Salaverría, Ramón (ed.). Diversity of Journalisms. Conference Proceedings (CICOM+ECREA). Pamplona: Servicio de Publicaciones de la Universidad de Navarra: 83-91.

CAVAlLO, GUglielMO; CHARTIER, ROGER (dir.) (1998). Historia de la lectura en el mundo occidental. Madrid: Taurus.

COHEN, DANIEL; ROZENZWEIG, ROY (2005). Digital History: A Guide to Gathering, Preserving, and Presenting the Past on the Web. Philadelphia: University of Pennsylvania Press <http://chnm.gmu.edu/digitalhistory/>. Accessed: November 24, 2011.

DARNTON, R. (1999). The New Age of the Book. The New York Review of Books, March 18 <http://www.nybooks.com/articles/archives/1999/mar/18/the-new-age-ofthe-book/?pagination=false $>$. Accessed: November 15, 2011.

DEEGAN, MARILYN; STEINVEL, EMIL; KING, EDMUND (2002). Digitizing historic newspapers: progress and projects. RLG DigiNews, 6 (4) < http://www.rlg.org/preserv/diginews/index.html>.

DEUZE, M. (2008). Understanding Journalism as Newswork: How It Changes, and How It remains the Same. Westminsters Papers In Communication and Culture. London: University of Westminster.

DÍAZ NOCI, JAVIER (1999a). Digital publishing: Electronic books, journals and newspapers on the Internet. Workshop on Digital Publishing and Education, Department for Continuing Education, University of Oxford, 14th May, 1999. <http://www.ehu.es/diaz-noci/Conf/C18.pdf>. 
DILLER, H. J. (2000). Kenneth Starr and Us. The Internet and the Vanishing of the Journalist. Ungerer, F. (ed.). English Media Texts Past and Present. Language and Textual Structure. Amsterdam; Philadelphia: John Benjamins Publishing Company: 197-213.

EISENSTEIN, E. (1979). The printing press as an agent of change: communications and cultural transformations in early modern Europe (2 vols. ed.). Cambridge UK: Cambridge University Press.

ELMER-DEWITT, P. (1995). Welcome to Cyberspace. Time, 145(12): <http://www.well.com/ ped/clips/Cyberspace_Cover_Spring.95>. Accessed: November 24, 2011.

FOGEL, JEAN-FRANÇOIS; PATIÑO, BRUNO (2005). Une Presse sans Gutenberg. Paris: Grasset \& Frasquelle.

GRACIA CÁRCAMO, JUAN (2005). Medios y formas de comunicación en el Bilbao contemporáneo (siglos XIX-XX). Reflexiones desde la historia sociocultural. Medios y empresas de comunicación. Bidebarrieta. Revista de Humanidades y Ciencias Sociales de Bilbao. Bilbao: Ayuntamiento de Bilbao, 29-86.

GREER, J.; MENSING, D. (2003). The evolution of Online Newspapers: A longitudinal content analysis, 1997-2003, Newspaper division of the Association for Education in Journalism and Mass Communication for the 2003 annual conference.

- (2006). Early Trends in Online Newspaper Content. Li, Xigen (ed.) (2006). Internet Newspapers: The Making of a Mainstream Medium. Mahwah, NJ: Lawrence Erlbaum: 13-32.

GUALLAR, JAVIER; ABADAL, ERNEST (2010). The digital press archives of the leading Spanish online newspapers. Information Research, 15(1): <http://informationr.net/ir/15-1/paper424.html>. Accessed: November 24, 2011.

HERSCOVITZ, HELOIZA G. (2009). Brazilian News Portal Characteristics. Brazilian Journalism Research 5(1): 99-122.

HIGGS, EDWARD (ed.) (1998). History and electronic artefacts. Oxford: Clarendon Press.

HUNT, LYNN (ed.) (1989). The new cultural history. Berkeley etc.: University of California Press.

KEEFER, A.; GALLART, N. (2007). La preservación de recursos digitales: el reto para las bibliotecas del siglo XXI. Barcelona: UOC. 
MCLUHAN, MARSHALL (1994). Understanding Media. The Extensions of Man. Cambridge, MA; London: The MIT Press.

MEYER, P. (2009). The Elite Newspaper of the Future. American Journalism Review, October/November <http://www.ajr.org/Article.asp?id=4605>. Accessed: December 3, 2009.

- (2010). La supervivencia en la Web 3.0. Infoamérica. Iberoamerican Communication Review, Cátedra Unesco de la Universidad de Málaga, 2: 39-57.

PAVLIK, JOHN (2001). Journalism and new media. New York: Columbia University Press. - (2004). A Sea-Change in Journalism: Convergence, Journalists, their Audiences and Sources. Convergence, 10: $21-29$.

PRENSKY, M. (2001). Digital Natives, Digital Immigrants. On the Horizon, 9 (5). $<$ http://www.marcprensky.com/writing/Prensky\%20-

\%20Digital\%20Natives,\%Digital\%20Immigrants\%20-\%20Part1.pdf>. Accessed: October 15, 2011.

SALWEN, M.B.; GARRISON, B.; DRISCOLL, (eds.). Online news and the public. Mahwah, $\mathrm{NJ}$ : Lawrence Erlbaum.

SMARTT, M. (2007). The days before launch. BBC Internet Blog <http://www.bbc.co.uk/blogs/bbcinternet/2007/12/the_days_before_launch.ht ml>. Accessed: November 24, 2011.

SMITH, ANTHONY (1980). Goodbye Gutenberg. The Newspaper Revolution of the 1980's, Oxford-New York: Oxford University Press.

- (2010). El periódico que viene. Reconstrucción del escenario mediático. Infoamérica. Iberoamerican Communication Review, Cátedra Unesco de la Universidad de Málaga, 2: 7-19.

STARR, P. (2009). Goodbye to the Age of Newspapers (Hello to a New Era of Corruption). Why American politics and society are about to be changed for the worse. The New Republic < http://www.tnr.com/article/goodbye-the-agenewspapers-hello-new-era-corruption?page=1>. Accessed: December 3, 2009.

THORSEN, E. (2008). Journalistic objectivity redefined? Wikinews and the neutral point of view. New Media \& Society, 10(6): 935-954.

- (2010). BBC News Online: A Brief History of Past and Present. Brügger, N. (ed.). Web History. New York, etc.: Peter Lang: 213-232.

THORSEN, E.; ALLAN, S.; CARTER, C. (2010). Citizenship and Public Service: The Case of BBC News Online. Tunney, S. and G. Monaghan (eds.). Web Journalism: A New Form of Journalism? Sussex: Sussex Academic Press: 116-123. 
TREMAYNE, M.; WEISS, A.S.; ALVES, R.C. (2007). From product to service: The diffusion of dynamic content in online newspapers. Journalism \& Mass Communication Quarterly, 84(4): 825-839.

TUNNEY, S.; MONAGHAN, C. (eds.) (2010). Web Journalism: A New Form of Journalism? Sussex: Sussex Academic Press.

VAN DEN HEUVEL, CHARLES (2010). Web Archiving in Research and Historical Global Collaboratories. Brügger, N. (ed.). Web History. New York, etc.: Peter Lang: 280303.

WHITE, DAVID S.; LE CORNU, ALISON (2011). Visitors and Residents: A New Typology for Online Engagement. First Monday, 16 (9). <http://fristmonday.org/htbin/cgiwrap/bin/ojs/index.php/fm/article/viewArticle /3171/3049>. Accessed 15 October 2011. 